\title{
Political Communication, Television Advertising and Elections in Brazil: A Longitudinal Analysis of Two Major Parties' Use of Free Electoral Advertising Time
}

\author{
Michele Massuchin 1 \\ https://orcid.org/0000-0001-7918-4487 \\ Fernanda Cavassana ${ }^{2}$ \\ https://orcid.org/0000-0003-1668-3160 \\ Emerson Cervi ${ }^{3}$ \\ https://orcid.org/0000-0001-8073-014X
}
${ }^{1}$ Universidade do Estado do Rio de Janeiro, Institute of Social and Political Studies, Rio de Janeiro/RJ, Brazil
${ }^{2}$ Universidade Federal do Paraná, Postgraduate Program in Communication, Postgraduate Program in Political Science, Curitiba/PR, Brazil
3Universidade Estadual de Ponta Grossa, Ponta Grossa, Brazil

A longitudinal analysis of the use of televised electoral advertising by the two political parties that have been the central actors in presidential elections in post-democratization Brazil: the Workers' Party (hereinafter referred to using the Portuguese acronym the 'PT') and the Brazilian Social Democracy Party (hereinafter referred to using the Portuguese acronym the 'PSDB'). Our objective is to identify patterns and changes in Brazilian electoral advertising between 2002 and 2018 with reference to Brazil's system of free electoral advertising time (hereinafter referred to using the Portuguese acronym 'HGPE'), more of which has been allocated to these two parties than to any other. Despite the increasing use of other forms of electoral campaigning, HGPE is central to presidential contests and demarcates political time and parties' agendas. It is therefore relevant to understand how use of this campaign component has been developed over time, taking into account two factors: messages and strategies. Our quantitative content analysis considers 90 days of PT and PSDB block format advertising during the first rounds of five election contests. Our results reveal that changes in messaging tend to be decided on by the parties (with the PT emphasizing public policies and the PSDB emphasizing image building) whereas the strategies employed depend on the context of each election and are less specific to either party.

Keywords: Elections; Brazil; election campaigning; television advertising, HGPE.

http://doi.org/10.1590/1981-3821202100030003

For data replication, see: https://doi.org/10.7910/DVN/QOK8WQ

Correspondence: Michele Massuchin.E-mail: mimassuchin@gmail.com

This publication is registered under a CC-BY Licence. 


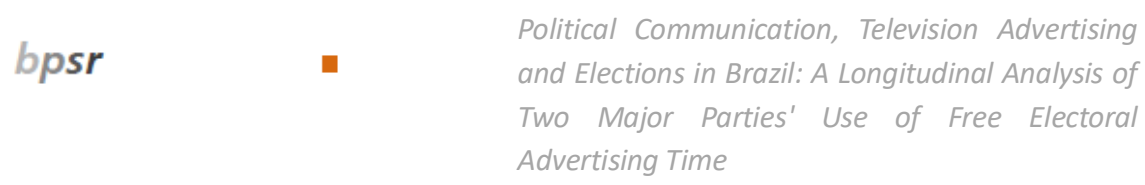

This article performs a longitudinal analysis of the uses of free electoral advertising time (HGPE) in Brazilian presidential elections from 2002 to 2018 with reference specifically to the uses made of it by the Workers' Party (PT) and the Brazilian Social Democracy Party (PSDB). These two parties accounted for the lion's share of the HGPE in the five elections held in the period and were the key players in four of them. The HGPE is the principal advertising space available to Brazilian political parties during election campaigns and has therefore been a popular subject for communications and political science research.

Even with the growth of such other platforms as the Internet and social media, television remains the medium that reaches the greatest number of Brazilians (BRASIL, 2016). Whereas common sense suggests that the public largely ignores political campaign advertising - although this is contested by Dias (2013) - and there are some studies that suggest its influence depends on context (ALBUQUERQUE; STEIBEL, and CARNEIRO, 2008), other research has shown that in contemporary democracies HGPE provides public visibility to parties, proposes certain themes for debate, draws attention to certain specific causes and delimits electoral coalitions. In the case of first-past-the-post presidential elections, a mediatized campaign becomes necessary to build a candidate's image, given the difficulties of carrying out a large-scale door-to-door campaign. Furthermore, HGPE is a way of setting aside specific time for politics, divulging an agenda-setting image and expressing the interests of the political elite - an elite that totally controls this type of electoral communication (ALBUQUERQUE, 1999; CERVI, 2011; DIAS, 2013; VEIGA, 2017).

A significant number of studies of HGPE analyze specific elements or restrict themselves to a sole election. Noteworthy exceptions include the studies undertaken by Borba (2015), Dias (2013) and Freitas (2018). The absence of such studies is noted and provides ample justification for this article as a way of expanding analysis of HGPE. To this end, we investigated how the PSDB and the PT, whose party coalitions allowed them obtained the lion's share of HGPE between 2002 and 2018, developed their HGPE programs by examining the database produced by the Political Communication and Public Opinion research group at the Federal University of Paraná (CPOP-UFPR).

Our research question: How has the use of Brazilian presidential HGPE been developed over time by the main parties competing in elections? Our objective is to 
compare the elements of the parties' HGPE programs and their performance in television advertising in the five presidential contest that we looked at, by seeking to identify ruptures and continuities, both between the parties and between elections. We considered the total number of the parties' programs in the first rounds of the elections of $2002,2006,2010,2014$ and 2018 and focused on the two fundamental elements for characterizing HGPE use: the theme presented and strategies employed.

The article is divided into four parts. The first part discusses the roles assumed by the two parties in Brazilian presidential contests. The second part concerns the centrality and characteristics of HGPE as a campaign tool. The third part details our research, as well as the variables and categories analyzed. The fourth part presents our data analysis and conclusions.

\section{Presidential elections in Brazil and the roles of the PSDB and the PT}

This article analyzes the development of the use of HGPE by the only two political parties whose presidential candidates were elected to office in the two decades subsequent to the re-democratization period: the PSDB and the PT. This duopolization of the presidency over such a long period transformed Brazil's multiparty system into an essentially bipartisan one - at least insofar as the presidency is concerned - and had an important effect on local elections (LIMONGI and GUARNIERI, 2014).

This led to other parties orbiting around the two poles of the PT and the PSDB (D'ARAÚJ0, 2011) and made the two parties the most mentioned in public opinion surveys of party political sentiment (SILVA, 2012). In 2002, the PSDB and the PT together accounted for $69.63 \%$ of valid votes cast in the first round of the presidential election. In 2006, they accounted for $90.25 \%$ of valid first-round votes; the figure for 2010 was 79.52\%; and for 2014 it was $75.15 \%$. Clearly most votes were cast for these two parties. The exception was the election of 2018, in which together they received only $34.04 \%$ of valid votes. In the 2018 election, the PSDB did not make it into the second round in spite of having the largest share of HGPE. The PSDB candidate, Geraldo Alckmin, came in fourth place, behind Jair Bolsonaro of the Social Liberal Party (PSL), Fernando Haddad of the PT and Ciro Gomes of the Democratic Labor Party (PDT).

Following the promulgation of the 1988 Constitution, socially relevant parties gained political prominence in Brazil. The PT and the PSDB stood out for their roles in 


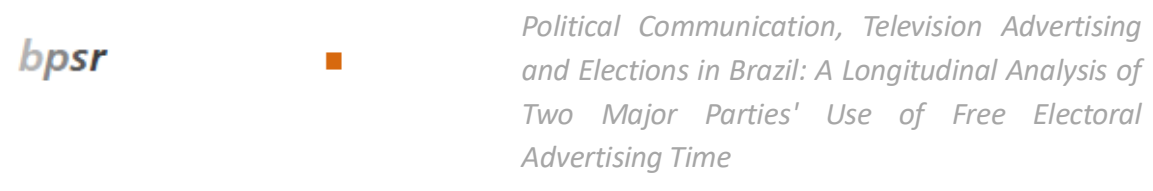

the institutionalization of democracy after the end of the military dictatorship, and for being based in social democracy, understood as the defense of inclusive social reforms (D'ARAÚJO, 2011, p. 67). There was an ideological proximity between the two parties that was visible until 1992; from the 1994 elections onwards they began to diverge. This divergence has led to electoral polarization in respect of the best economic model for government (FREITAS, 2018, p. 550).

The PSDB stayed in government for eight years, starting with the election of President Fernando Henrique Cardoso (FHC) in 1994 and continuing with this reelection in 1998. The FHC government was marked by 'governability' that was made possible by Congressional support that allowed the Presidency to enact its agenda - so much so that the legislature at times distanced itself from public demands. Monetary stability and reforms to control inflation and incorporate Brazil into the global economy were prioritized, unlike socio-economic inequality and similar matters, which were not (FIGUEIREDO; LIMONGI, and VALENTE, 1999).

At the end of its second term, the FHC government enjoyed the approval of only a minority of voters (DATAFOLHA, 2002). In 2002, the PT candidate Luiz Inácio 'Lula' da Silva launched his campaign with his famous 'Letter to the Brazilian People', which combined criticism of the FHC administration's economic policies with discourse that connected social development to economic development ${ }^{1}$. Lula's letter highlighted the importance of the economic stability of the 1990s, which according to D'Araújo (2011) testifies to the PT's adaptation to a "more pragmatic and less classist or statist" position (D'ARAÚJO, 201, p. 71). The transition following the 2002 election saw no major changes in macroeconomic policy but there was an expansion and consolidation of social policies (D'ARAÚJO, 2011).

Lula stood for reelection in 2006 and, according to Machado (2009), campaigned with a discourse of "defending the continuity of the economic growth model, while simultaneously enabling development in the social area" (MACHADO, 2009, p. 163). The emphasis on the economy stayed in place but was coupled with advances in income transfer and reduced social inequality. It is worth remembering that the topic of corruption came to the fore in the 2006 election in the aftermath of the

${ }^{1}$ Available in full at: <https://www1.folha.uol.com.br/folha/brasil/ult96u33908.shtml>. Accessed on July, 12, 2020.

(2021) 15 (3) - e0003-4/33 
so-called 'Mensalão' scandal. Geraldo Alckmin, the PSDB candidate, emphasized his individual political capacity and achievements as a leader in other spheres (DIAS, 2012).

In the 2010 election the PT candidate was Dilma Rousseff and the PSDB candidate was José Serra. Although Rousseff was the PT candidate, the influence of former president Lula could be directly felt, according to Reis (2014). By contrast, the PSDB dedicated itself to building up the image of José Serra as a politician and administrator, mainly by highlighting his work as governor of São Paulo (OLIVEIRA and MARTINS, 2013), a state where most voters opposed the Lula government (CERVI, 2016).

In 2014, Dilma Rousseff was the PT's incumbent candidate. She faced with major criticisms of her administration, given the high profile of the anti-corruption operation known as 'Lava-Jato' and accusations of corruption at Petrobras, the Brazilian state-owned enterprise. This election came soon after the 2013 mass protests, which, while diffuse and lacking unified objectives, had highlighted popular dissatisfaction with the governing class and represented an anti-political and antiinstitutional movement (REIS, 2014). Reis (2014) points out that social policy became a priority that was not restricted to the PT campaign in 2014 and that the economic agenda also played a major role. These themes were exploited as part of PSDB candidate Aécio Neves' attack strategy.

The 2018 election political scenario was an outlier compared with previous years' and represents the culmination of a political and institutional crisis that had been building since President Rousseff's first term in office and was consolidated with her impeachment and the rise of Operation Car Wash. This was a contest not centered on bipartisanship. The PT candidate was initially Lula, who was later replaced by Fernando Haddad. The PSDB candidate was once again Geraldo Alckmin, whose candidacy included highlighting his anticorruption credentials, indicating the need for reforms, including political reforms ${ }^{2}$, endorsing neoliberal economics and a undertaking a sustained campaign of attacks on opponents, especially Bolsonaro. Haddad tried to draw attention to the Lula Government's achievements in the areas of

${ }^{2}$ A general outline can be viewed at: <http://divulgacandcontas.tse.jus.br/candidaturas/oficial/2018/ BR/BR/2022802018/280000602477/proposta_1533849607885.pdf >. Accessed on July, 12, 2020. 


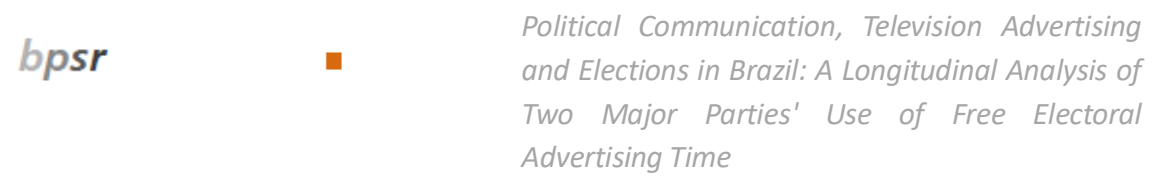

social welfare (BORBA and MEDEIROS, 2019). The anti-PT sentiment known in Portuguese as 'antipetismo' influenced the way the election played out, as did the crisis of legitimacy affecting institutionalized political parties like the PSDB (BORGES and VIDIGAL, 2018). This combination of factors led to the election of Jair Bolsonaro (PSL), whose campaign was essentially centered on the figure of Bolsonaro himself and cannot be considered an indication of the strength of the PSL party (DIAS and FERNANDES, 2020), which did not enter into a coalition with any other parties in the election.

It is worth noting that in spite of their different ideological and administrative approaches, both PT and PSDB administrations were "characterized by financial stability, consistent social policies aimed at reducing social and regional inequality, a search for economic growth, pro-environmental policies and respect for legal and constitutional provisions" (D'ARAÚJO, 2011, p. 66). Over the period of these governments, economics became central to public and electoral debates. Brazil's history of inequality meant that social policies were also at the center of electoral debates (REIS, 2014), as reflected in HGPE.

With the benefit of hindsight, it is clear that voters tended to decide whom to vote for on the basis of public policies (DIAS, 2012). This can be observed geographically, whereby a given location's HDI, as a measure of economic, health and educational data, can serve as an indicator of electoral success. Twenty years of electoral contests between the PT and the PSDB showed that "votes for the governing party are associated with dependency on public policies in given geographies, and votes for the opposition depend on the failure of these policies" (CERVI, 2016, p. 313). This is the reason why when the PT was in government it gained more votes in states with higher HDI growth, whereas the PSDB gained more votes in states with lower HDI growth (CERVI, 2016).

This is of interest for our analysis in terms of the PT and the PSDB's use over time of HGPE to focus on public policies. In the 2002 to 2018 elections, this means thinking about how the two parties leveraged public policy themes from their respective incumbent and challenger perspectives. As the tool we are looking at is HGPE, the next section will consider its main characteristics and the possibilities for analysis. 


\section{HGPE as a source of electoral information}

Advertising is currently a relevant tool in electoral contests and can be considered a relevant variable in the voter decisions, especially where votes are cast on the basis of rational choice, given that this is more susceptible to media and campaigning because of the weight of the informational variable in decision making (TELLES and MUNDIM, 2015). This is especially true where there are undecided voters and in democratic scenarios with high electoral volatility. Election campaign advertising is defined as a space in which candidates and parties present themselves to the electorate, especially through the media, from their own space and not through the press. Party and candidate advertising is especially important because it allows for autonomy and control over messaging (HOLTZ-BACHA and KAID, 2006). However, as such campaigns are not watertight, there is a modernization process underway that directly affects the way electoral advertising is produced (MANCINI and SWANSON, 1996) and is associated with increased professionalization.

The mediatization of politics (STRÖMBÄCK, 2008) has given television a central place in political contests. In Brazil, television is still one of the most widelyused means of obtaining information and is present in $96.7 \%$ of households ${ }^{3}$ (BRASIL, 2016; IBGE, 2017). Television advertising is therefore an important element that has a particular influence on the formation of party coalitions. Party institutions invest in coalitions to obtain more HGPE as an increased media presence tends to lead to satisfactory results, with candidates making it through to the second round (BORBA, 2015). In four of the five elections we looked at (the exception being 2018), the candidates who made it through to the second round were those who had had the most HGPE.

As well as being used to demarcate 'politics time' in the eyes of voters (CERVI, 2011) HGPE is one of the main tools available to Brazilian political parties and candidates. It is noteworthy that the impacts of HGPE vary according to candidate type, especially in the case of candidates with an existing voter base (ALBUQUERQUE; STEIBEL, and CARNEIRO, 2008). The functions of HGPE also vary by election type. In

\footnotetext{
${ }^{3}$ Based on the question: 'And which communication medium is the one you get the most information from about what is happening in Brazil? And which is the next one after that?' Discussion of methodological criticisms of self-declaration is beyond the scope of this article, which seeks to analyze the uses of HGPE. The data is used as additional information to reinforce the centrality of HGPE.
} 


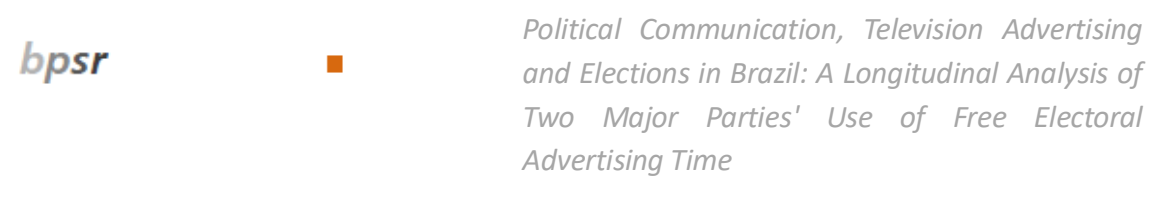

first-past-the-post elections, it offers a space that allows for both thematic discussion and image formation, especially for coalition candidates with more HGPE time. In proportional elections, HGPE has the primary function of presenting the candidates so that the voters will search for more information about them by other means.

The first empirical studies of HGPE use investigated the discursive strategies employed by the candidates and the structure of their HGPE (ALBUQUERQUE, 1999; FIGUEIREDO et al. 1997). Studies of electoral campaign advertising have been undertaken since the 1989 elections. The literature on the subject reflects at least three different approaches, the first bringing together studies of HGPE structure and language, the second analyzing of the strategies used and the third looking at its impacts (ALBUQUERQUE and TAVARES, 2019). Albuquerque (2009) presented some insights into possible future lines of research. Among other suggestions, he pointed out that greater attention should be paid to negative campaigning, proportional elections and the importance of political marketing professionals in campaigns (ALBUQUERQUE, 2009). These approaches were developed by other authors who looked at HGPE from specific angles.

As regards negative campaigning, it is important to note that attacks receive as much attention as other forms of advertising (LAU et al., 1999). This type of strategy, widely employed in American political campaigns, has been used by Brazilian candidates, especially those in opposition, since 2002 (BORBA, 2015; LOURENÇO, 2009). International studies have placed greater emphasis on the effects of this strategy than the forms it takes. Research in the last decade had exhibited a tendency towards observing proportional election advertising (CERVI, 2011; MIGUEL, 2009), and few studies have focused on the political party perspective and their relationship with HGPE (ALBUQUERQUE; STEIBEL, and CARNEIRO, 2008; CARNEIRO and SCHIMITT, 1995; SCHMITT, CARNEIRO, and KUSCHNIR, 1999). The study of the importance of marketing and communication professionals in campaigns has intensified as campaigns have modernized.

Despite the centrality of HGPE in all elections since 1989, Albuquerque and Tavares (2019) highlight changes that have taken place since HGPE has started to share advertising space with the social media platforms that have become widely used in 
electoral campaign communication. They also point out that the time allotted for HGPE was reduced by Law № 13,165 of 2015, which also imposed limitations on contributions (that tended to be spent on television advertising) from legal persons. HGPE has been obliged, therefore, to divide its space with an increasing plurality of other media, in addition to the other challenges television advertising faces.

\section{HGPE themes and strategies analyzed over time}

This article analyzes two specific variables over time, i.e. campaign themes and discursive strategies, which are looked at in terms of content and mode of transmission. Time can be a vector of changes that can be identified in the elections that we looked at and can shape different political interests longitudinally. Observing the elections longitudinally makes sense considering the importance of time as a factor in shaping them. Among other studies, we find that Figueiredo et al. (1997) were a useful source for consideration of strategy and that the views of Dias' (2013; 2012) in respect of parties and their different approaches were a valuable source for consideration of HGPE. We wish to reinforce the fact that our study concerns neither the development of a campaign in the course of an election year nor evaluations of governments, as per Stimson (1976) with his cyclical model, but constitutes a longitudinal analysis that brings together different campaigns over almost 20 years. We treat time as a unit of selection for comparisons and not as an explanatory variable.

Regarding the first dependent variable, our concern is to identify which themes and/or proposals are present in the electoral contest, which theme is related to a specific type of message and which theme seeks to identify problems and propose solutions (ALBUQUERQUE, 1999; ALBUQUERQUE and TAVARES, 2019). Although some studies have found that campaigns tend not to propose a great deal and to emphasize image formation to the detriment of public themes (SOUZA; CERVI, and SANTOS, 2009), others find that themes gain space among the types of messages transmitted (MASSUCHIN et al., 2016; PENDIUK, 2013) and that issues that refer to the context of the election can be of great prominence, as with economics in the 1994 election (PORTO and GUAZINA, 1999).

Considering the different approaches to use of GPE, our hypotheses are that (H1) the weight of thematic content differs by party throughout the trajectory of the five elections, with such changes as occur explainable by reference to the parties 


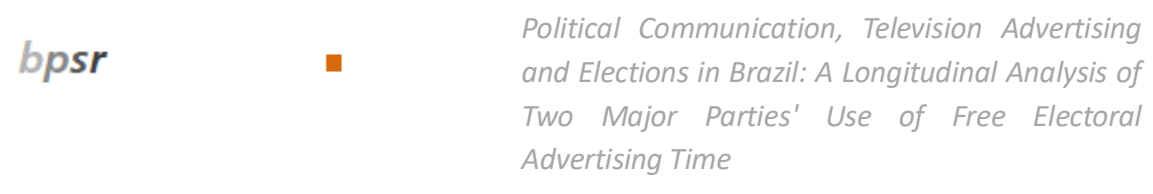

themselves and not by temporal evolution. This hypothesis is based on the understanding that political parties differ ideologically and therefore tend to engage in advertising differently, in the same way that they tend to form coalitions that match their ideological preferences (CARREIRÃO, 2006). Party specificities come first, despite differences inherent to the candidates themselves since, especially in the case of the $\mathrm{PSDB}^{4}$, candidates were replaced in one election after another, as were the positions occupied in each election. This is related to the party differences exposed in previous topics. The extent to which HGPE is used thematically varies according to the party distinctions and not any temporal evolution that might have changed the way that HGPE programming is constructed or brought the parties closer together.

Public themes compete for space with other kinds of HGPE content, such as image formation (ALBUQUERQUE, 1999). There is also the meta campaign, a type of auxiliary message with facts external to HGPE, such as research or the candidate's agenda, inter alia.

Discursive strategies are used with a view to persuading and convincing voters (FIGUEIREDO et al., 1997). Albuquerque and Tavares (2019) point out that HGPE already has pre-defined times and structures, which does not allow for radical production changes. The strategies are responsible, complementarily, for the way candidates choose to speak to the public, by highlighting different elements and ways of communicating content. These strategies have changed as campaigns have modernized. Dias (2013) shows that candidates can emphasize political parties, which is relevant for institutions. Tavares (2013) discusses how candidates can take advantage of political support from patrons in their advertisements, while Borba (2015) and Lourenço (2009) highlight the use of negative campaigning. There are also strategies that characterize the discourse of the incumbent president and/or his or her challenger (FIGUEIREDO et al., 1997). The strategies chosen are linked to the party's position in the contest rather than to the party itself.

In view of the foregoing, we also hypothesize (H2) that strategies vary according to a given candidate's position in an election, with no significant temporal or

${ }^{4}$ In some cases the PT nominated the same candidates in multiple elections, unlike the PSDB.

(2021) $15(3) \quad$ - $\quad$ e0003-10/33


partisan influence. Party and time therefore have less weight in the definition/maintenance of a strategy, unlike HGPE theme-setting.

In respect of strategies, we focused on four elements - 'endorsement, attack, call for change and use of office' - all of which are prominent in the literature and present in the scenario analysis of Figueiredo et al. (1997). They were less interested in the effects of these elements than in the ways they are used according to the electoral scenarios that distinguish competitors. 'Endorsement' and 'use of office' are typical of candidates whose party is in power while 'call for change' and 'use of office' are typical of challenger candidates.

Unlike Stimson's repeated cycle (1976), here we see perennial characteristics, such as thematic distinctions, as well as characteristics that change precisely because each contest takes place in a specific context. The PT and the PSDB were at times incumbents and at times challengers, which was an important factor in the strategies they adopted, according to the logic of the possible worlds and the evaluations made by Figueiredo et al. (1997).

\section{Methodological aspects of the research}

Following in the footsteps of Bauer (2012) and Krippendorff (1990), the CPOPUFPR research group undertook content analysis of the HGPE block format programs broadcast during the presidential elections of 2002, 2006, 2010, 2014 and $2018^{5}$. These were categorized according to elements present in the literature (ALBUQUERQUE, 1999; FIGUEIREDO et al., 1997) that have been maintained over time, which allowed for longitudinal analysis. The collection was made using a coding book containing several categorical variables that characterize the content of each program segment - i.e. an autonomous video excerpt - with thematic, speaker and defined environments (CERVI, 2011; PANKE and CERVI, 2011).

We had to demarcate our field, as reflected in our decision to focus on the PT and the PSDB, the parties that disputed the five elections, whether they obtained a higher percentage of votes or more time on television. The fact that the same parties participated in the five elections allowed us to identify aspects that were maintained

5Precisely for this reason, this article does not analyze the 1994 and 1998 elections. Studies of electoral advertising for that group started in 2002. 


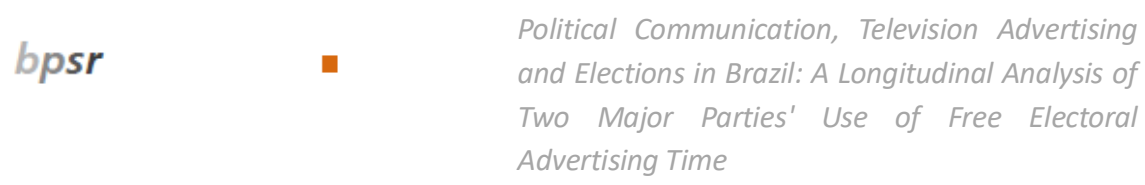

over time. We chose to restrict our analysis to the first round of each election, which gave us more than 19 hours of video content in total.

Our analysis looks at two characteristics: strategies and themes. The strategies in question concern the candidate's communicative persuasive resources (FIGUEIREDO et al., 1997). The CPOP research group classified the strategy variable according to 10 categories, which can appear concurrently, and which are aggregated here into four types: 'endorsement, attack, call for change' and 'use of office'. 'Endorsement' refers to an appearance by another actor on an HGPE segment as a means of reinforcing the vote for a given candidacy. 'Attack' seeks to demobilize votes for an opponent (BORBA, 2015). 'Call for change' reinforces the message that 'it is time for a change' by highlighting the situation that needs to be changed (FIGUEIREDO et al., 1997). 'Use of office' encompasses messages in which the candidate addresses his or her political and administrative experience in his or her activities prior to the election. All are shown in Table 01. They include challenging strategies, which call for change and attack the status quo by emphasizing criticism of the 'bad' and presenting the viability of a new and 'good' government. The strategies of incumbent-aligned candidates tend to present the qualities of the current administration by characterizing the status quo as good and proposing improved continuity (FIGUEIREDO et al., 1997).

In this study we employed the thematic categories proposed by Albuquerque (1999). Themes matter for the construction of persuasive and strategic campaign communication that can address the incumbent government's proposed program, discuss issues of interest to the public, present candidates and coalition parties and address aspects of the campaign itself, such as any rules or specific events. We started out with 34 mutually exclusive possibilities divided into three main groups, as detailed in Chart 01.

It is important to consider aspects related to the time occupied by the two parties in the electoral advertising we analyzed. HGPE is divided up among all parties and coalitions according to criteria established by law, with a small part equally distributed among candidates and another part distributed proportionally according to party presence in the Chamber of Deputies (BRASIL, 1997). Candidates representing larger coalitions therefore have access to more HGPE.

(2021) $15(3) \quad$ - e0003-12/33 
Chart 01. Variables and groups of categories brought together for analysis: i) Attacks on incumbent administration; ii) Attacks on opponents.

\begin{tabular}{|c|c|c|}
\hline Variable & $\begin{array}{l}\text { Grouped } \\
\text { categories }\end{array}$ & Initial categories \\
\hline \multirow[t]{4}{*}{$\begin{array}{l}\text { Discursive } \\
\text { strategies }\end{array}$} & Use of office & $\begin{array}{l}\text { i) Use of office; ii) Association with incumbent } \\
\text { administration in election/emphasis on achievements; } \\
\text { iii) Association with administration in other position; }\end{array}$ \\
\hline & Endorsement & $\begin{array}{l}\text { i) Endorsement by political leaders; ii) Endorsement by } \\
\text { organized civil society leaders; iii) Endorsement by } \\
\text { patron; }\end{array}$ \\
\hline & Call for change & i) Call for change; \\
\hline & Attack & $\begin{array}{l}\text { i) Attacks on incumbent administration; ii) Attacks on } \\
\text { opponents. }\end{array}$ \\
\hline \multirow[t]{3}{*}{ Content } & $\begin{array}{l}\text { Public Policy } \\
\text { Themes }\end{array}$ & $\begin{array}{l}\text { i) Public security; ii) Health; iii) Education; iv) Tax; v) } \\
\text { Infrastructure and basic sanitation; vi) Economy; vii) } \\
\text { Urban development and urban planning; viii) } \\
\text { Sports/culture/leisure; ix) Transport; x) Environment; } \\
\text { xi) Employment; xii) Budget; xiii) Children; xiv) Elderly; } \\
\text { xv) Women; xvi) Civil service; xvii) Agriculture; xviii) } \\
\text { social welfare (scholarships, etc.); xix) Assorted (this } \\
\text { includes the segments in which there is no specific } \\
\text { theme, but a combination of several issues, almost } \\
\text { always only with the naming of the theme(s) when a } \\
\text { variety of specific public policies are presented); xx) } \\
\text { Other. }\end{array}$ \\
\hline & Image Building & $\begin{array}{l}\text { i) Image of city and metropolitan region; ii) Image of } \\
\text { state; iii) Image of country; iv) Image of candidate; v) } \\
\text { Image of party; vi) Image of opponent; vii) Image of } \\
\text { voter. }\end{array}$ \\
\hline & Meta-campaigning & $\begin{array}{l}\text { i) Electoral Research; ii) External campaign scenes; iii) } \\
\text { Calls for voter engagement; iv) Voter education; v) } \\
\text { Agenda; vi) Debate; vii) Campaign irregularities. }\end{array}$ \\
\hline
\end{tabular}

Source: Elaborated by the authors.

The elections analyzed here featured 45 days of presidential HGPE in the first four elections and 30 days of HGPE in 2018. This time was made up of televised block shows broadcast at $1 \mathrm{pm}$ and $8.30 \mathrm{pm}$, rather than 'spot' advertising. The corpus of material we worked with is therefore not homogeneous. Chart 02 details the information for each case and takes time as its unit of analysis ${ }^{6}$. The last column of the table shows the proportion of HGPE set aside for each candidacy in relation to the total set.

${ }^{6}$ Although our collection is made up of the segments, the choice of time as a unit of analysis allows greater fidelity to the information insofar as comparative analysis is concerned. 
Chart 02. Information about HGPE allocated to PSDB and PT in 1st rounds of elections of 20022018

\begin{tabular}{|c|c|c|c|c|c|c|}
\hline Election & Start & End & $\begin{array}{c}\text { Party } \\
\text { (Candidate) }\end{array}$ & Time/day* & Total time** & Proportion \\
\hline \multirow[t]{2}{*}{2002} & $20 / 08$ & $03 / 10$ & PSDB (Serra) & $10 \min 23 \mathrm{~s}$. & 2h35min20s. & 0.135 \\
\hline & \multicolumn{2}{|c|}{ (18 days) } & PT (Lula) & $5 \min 19 s$. & 1h29min42s. & 0.078 \\
\hline \multirow[t]{2}{*}{2006} & $15 / 08$ & $28 / 09$ & PSDB (Alckmin) & 10min22s. & 3h10min48s. & 0.166 \\
\hline & \multicolumn{2}{|c|}{ (19 days) } & PT (Lula) & 7min21s. & 1h59min56s. & 0.105 \\
\hline \multirow[t]{2}{*}{2010} & $17 / 08$ & $30 / 09$ & PT (Dilma) & 10min38s. & 3h11min02s. & 0.167 \\
\hline & \multicolumn{2}{|c|}{ (20 days) } & PSDB (Serra) & 7min18s. & 1h57min11s. & 0.102 \\
\hline \multirow[t]{2}{*}{2014} & $19 / 08$ & $02 / 10$ & PT (Dilma) & 11min24s. & 3h24min14s. & 0.178 \\
\hline & \multicolumn{2}{|c|}{ (18 days) } & PSDB (Aécio) & $4 \min 35 \mathrm{~s}$. & 1h18min54s. & 0.069 \\
\hline \multirow[t]{2}{*}{2018} & $1 / 9$ & $4 / 10$ & PT (Haddad) & $2 \min 41 s$ & $40 \mathrm{~min} 25 \mathrm{~s}$. & 0.268 \\
\hline & \multicolumn{2}{|c|}{ (15 days) } & PSDB (Alckmin) & $6 \min 12 \mathrm{~s}$. & 1h33min12s. & 0.620 \\
\hline Totals & \multicolumn{2}{|c|}{90 days of HGPE } & $\begin{array}{l}2 \text { parties and } 5 \\
\text { candidates }\end{array}$ & - & 19h07min04s. & 1.000 \\
\hline
\end{tabular}

Source: Elaborated by the authors, with data from the $\mathrm{CPOP}^{7}$ and the TSE(2020).

Notes: *Time initially estimated. There are variations in the daily duration of HGPE during campaigns.

**Total time of segments with content categorized as candidate HGPE in election.

Our corpus comprises 90 days' HGPE allocated to the PSDB and the PT that was broadcast in the 2002, 2006, 2010, 2014 and 2018 elections, totals more than 19 hours of video content ${ }^{8}$ and was analyzed with reference to the variables described above. We employed an analytical approach so as to make feasible a longitudinal and comparative analysis. This analysis is described in the next part of the article and considers the proportional time invested by the parties in each election and the hypotheses set forth above:

H1: the weight of thematic content differs by party throughout the trajectory of the five elections, with such changes as occur explainable by reference to the parties themselves and not by temporal evolution;

H2: strategies vary according to a given candidate's position in an election (incumbent or challenger), with no significant temporal or partisan influence.

${ }^{7}$ Database produced by the Political Communication and Public Opinion research group at the Federal University of Paraná (CPOP-UFPR).

${ }^{8}$ All of the HGPE segments were recorded while being broadcast and then watched and categorized by members of the research group. 
Content of HGPE messages: political-party distinctions in the use of advertising The first characteristic we explored was HGPE content, which was divided according to the themes of public policy, image building and meta-campaigning. Comparison the parties in Table 01 reveals that PT used its HGPE more thematically, while the PSDB focused its HGPE on image building, usually in respect of the candidate him/herself, as well as the images of his or her opponents, the party, voters, the country, and so on. There was therefore a noticeable difference between the parties that could be considered.

Table 01. HGPE content by party (2002-2018)

\begin{tabular}{llllll} 
& \multicolumn{2}{c}{ PT } & \multicolumn{2}{c}{ PSDB } & diff. pp \\
\cline { 2 - 6 } & \multicolumn{1}{c}{ Time seg. } & \% seg. & Time seg. & \% seg. & (PT-PSDB) \\
\hline $\begin{array}{l}\text { Public policy } \\
\text { Image }\end{array}$ & 23.032 & 57.4 & 17.997 & 43.7 & 13.7 \\
$\begin{array}{l}\text { Meta- } \\
\text { campaigning }\end{array}$ & 13.912 & 34.6 & 19.780 & 48 & -13.4 \\
\hline Total & 3.213 & 8 & 3.405 & 8.3 & -0.3 \\
\hline
\end{tabular}

Source: Elaborated by the authors, based on CPOP-UFPR.

The PT's public policy issues percentage exceeds that of the PSDB by 12 points. In respect of time dedicated to image building, the PSDB exceeds the PT by 13.7 percentage points. There is thus an inversion of content priority. In the case of metacampaigning, the two parties presented very similar percentages, with a difference of less than one percentage point (i.e., 0.3) between the PSDB and the PT. The comparison shows that the two parties are primarily distinguished by an inversion of theme and image. The PSDB expended similar amounts of HGPE on the two main content types, whereas the PT lavished palpably more space on campaign themes than image building.

Table 02 details the percentage of party time dedicated to each content in each election longitudinally, in addition to the difference in percentage points for the average. Temporal differences reinforce that fact that the two parties present themselves in a clearly distinct manner according to the weight given to theme and image building in their HGPE, even when the complex relationship between the political and media spheres is taken into account (MARQUES and CARNEIRO, 2018).

In the case of the PT, its 2002 and 2018 meta-campaigning HGPE is longer than the average, as is its image building in 2006 and 2010, and its public policy HGPE in 
2014, which occupied $71.1 \%$ of the party's total, i.e., 15.7 percentage points above the average. With the exception of 2006, the PT's HGPE was predominantly thematic, as per the data in Table 01.

Table 02. HGPE content by party and election (2002-2018)

\begin{tabular}{|c|c|c|c|c|c|c|c|c|c|c|c|c|}
\hline \multirow[b]{2}{*}{ Parties } & \multirow[b]{2}{*}{ Theme } & \multicolumn{2}{|c|}{2002} & \multicolumn{2}{|c|}{2006} & \multicolumn{2}{|c|}{2010} & \multicolumn{2}{|c|}{2014} & \multicolumn{2}{|c|}{2018} & \multirow[b]{2}{*}{ Average } \\
\hline & & $\begin{array}{l}\text { Time } \\
\%\end{array}$ & $\begin{array}{c}\text { diff. } \\
\text { Average } \\
\text { pp }\end{array}$ & $\begin{array}{l}\text { Time } \\
\%\end{array}$ & $\begin{array}{c}\text { diff. } \\
\text { Average } \\
\text { pp }\end{array}$ & $\begin{array}{l}\text { Time } \\
\%\end{array}$ & $\begin{array}{c}\text { diff. } \\
\text { Average } \\
\text { pp }\end{array}$ & $\begin{array}{l}\text { Time } \\
\%\end{array}$ & $\begin{array}{c}\text { diff. } \\
\text { Average } \\
\text { pp }\end{array}$ & $\begin{array}{l}\text { Time } \\
\%\end{array}$ & $\begin{array}{c}\text { diff. } \\
\text { Average } \\
\text { pp }\end{array}$ & \\
\hline \multirow[t]{3}{*}{ PT } & Public policy & 56.7 & 1.3 & 46.6 & -8.8 & 51.8 & -3.6 & 71.1 & 15.7 & 51 & -4.4 & 55.4 \\
\hline & Image & 21.8 & -12.7 & 51.1 & 16.6 & 45.4 & 10.9 & 21.1 & -13.4 & 33.2 & -1.3 & 34.5 \\
\hline & $\begin{array}{l}\text { Meta- } \\
\text { campaign }\end{array}$ & 21.5 & 11.5 & 2.3 & -7.7 & 2.8 & -7.2 & 7.8 & -2.2 & 15.8 & 5.8 & 10 \\
\hline \multirow[t]{3}{*}{ PSDB } & Public policy & 69.4 & 25.9 & 32.5 & -11 & 48.5 & 5 & 36.2 & -7.3 & 31.1 & -12.4 & 43.5 \\
\hline & Image & 22.3 & -25.1 & 65.5 & 18.1 & 33.8 & -13.6 & 55.6 & 8.2 & 60 & 12.6 & 47.4 \\
\hline & $\begin{array}{l}\text { Meta- } \\
\text { campaign }\end{array}$ & 8.3 & -0.7 & 2 & -7 & 17.7 & 8.7 & 8.2 & -0.8 & 8.9 & -0.1 & 9 \\
\hline
\end{tabular}

Source: Elaborated by the authors, based on CPOP-UFPR.

In the case of the PSDB, themes predominated in 2002 and 2010, while image building predominated in 2006, 2014 and 2018. Comparatively, in relation to the average, more time was dedicated to themes in 2002. Its 2006 HGPE was mainly dedicated to image building, being 20.4 percentage points above the average. In 2010, in addition to themes, there was more meta-campaigning and themes vis-à-vis the average. Proportionately longer time was dedicated to image building in 2014 and 2018. One possible explanation for this is that incumbent parties are more likely to emphasize a topic of knowledge (FIGUEIREDO et al., 1997) and dedicate more space to that.

Graphs 01 and 02 show that the PT consistently used its HGPE to emphasize themes over image-building, except in 2002. This demonstrates that the PT was more focused on addressing different public policy themes. The PT's use of HGPE shows a clear decline in image building over time, except in 2018, when the party's eventual candidate was Fernando Haddad, which led to a need for more image-building. The PSDB's predominant HGPE content changes considerably from one election to the next. This can be seen in its behavior vis-à-vis public policy themes, which are presented in low volume and with considerable declines when compared to the PT's HGPE use. The 
PT's HGPE use reveals significant longitudinal change, while that of the PSDB fluctuates year by year, despite the temporal predominance of image building.

Graph 01. Distribution of the general message of the PT and PSDB in HGPE 2002-2018 (\%) Longitudinal PT content ( $\%$ of time)

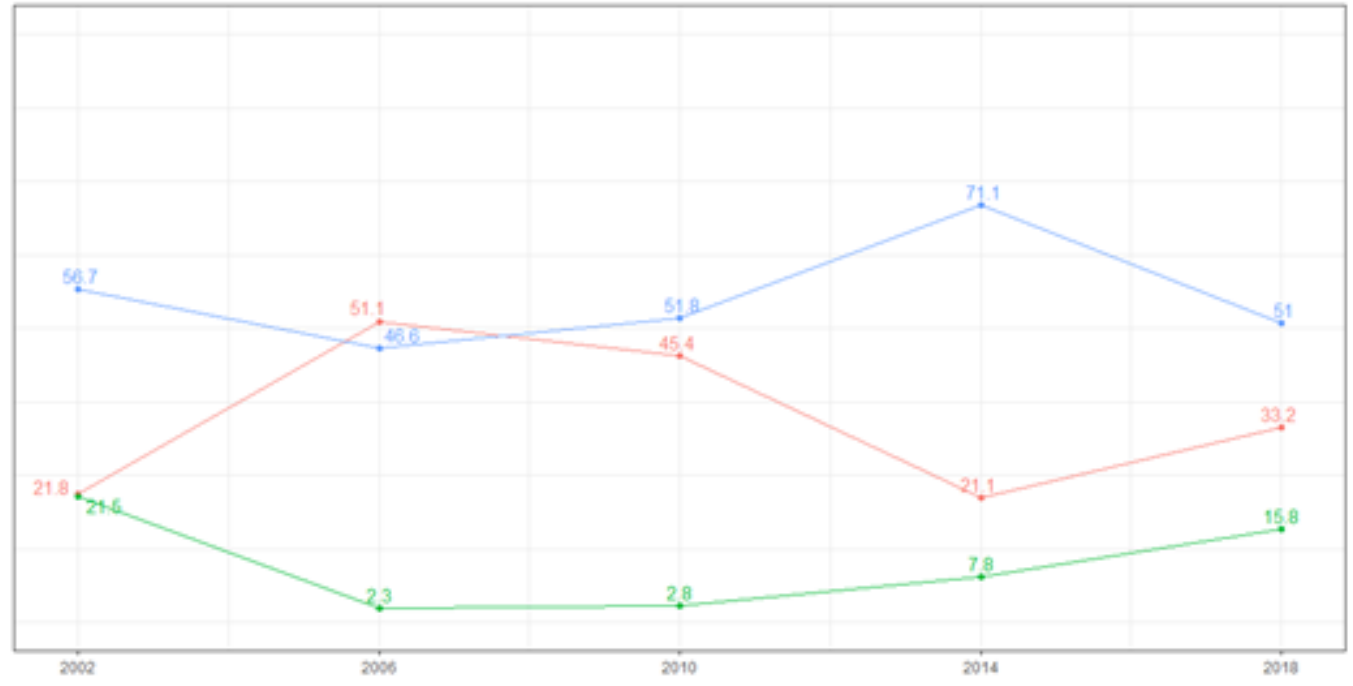

theme $\rightarrow$ image-building + meta-campaigning + public policy

Source: Elaborated by the authors, with data from the CPOP-UFPR.

Graph 02. Distribution of the general message of the PT and PSDB in HGPE 2002-2018 (\%) Longitudinal PSDB content ( $\%$ of time)

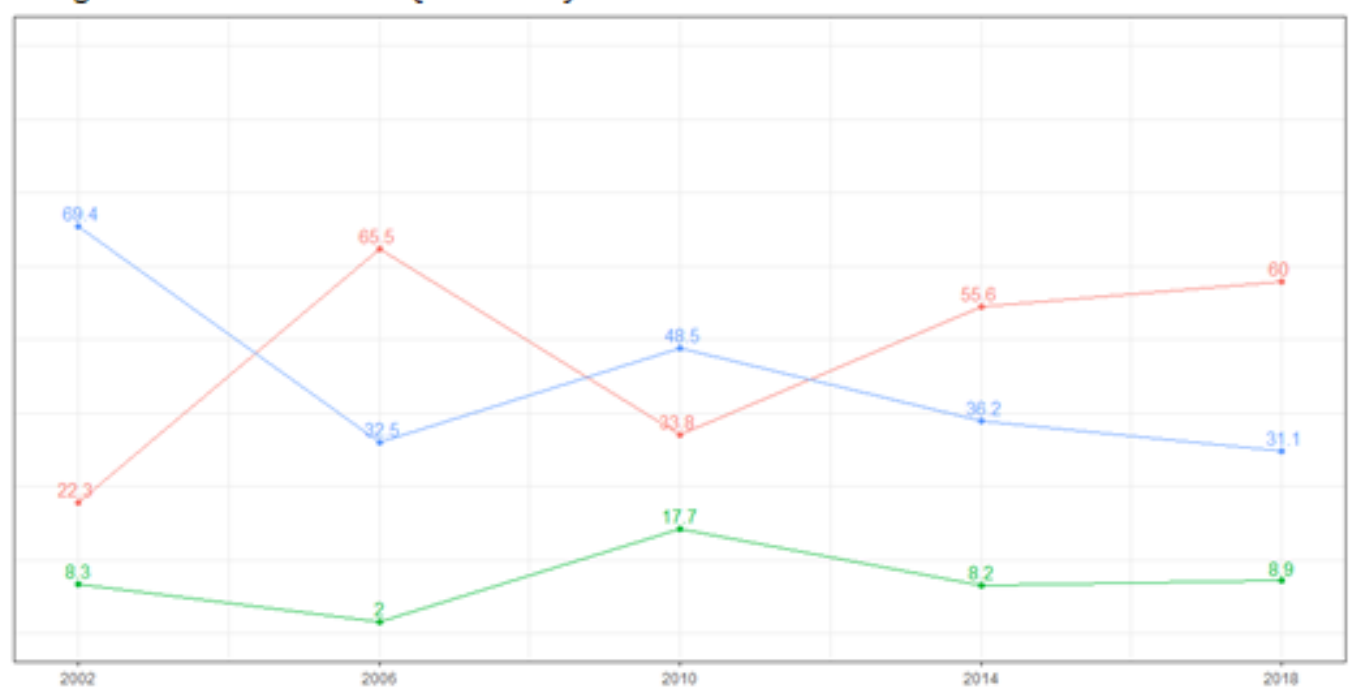

theme $\rightarrow$ image-building $*$ meta-campaigning $*$ public policy

Source: Elaborated by the authors, with data from the CPOP-UFPR. 


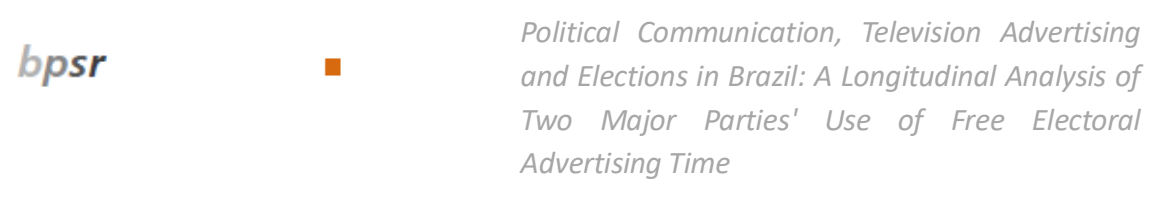

To complement the analysis of HGPE content, the Table 03 explores two possible public policy themes and compares the time allocated to them by the two parties. These are social welfare issues (e.g. inclusion policies such as the Bolsa Família and racial quota programs) and the economy (in macro-economic terms). As discussed in the theoretical section, these are important themes given the central roles of the PT and the PSDB in elections. Both themes end up being allocated more space by the PT than the PSDB. The data are similar to concerns present in government advertising (MADEIRA et al., 2017).

Table 03. Social welfare and the economy in HGPE by party and election

\begin{tabular}{|c|c|c|c|c|c|c|c|c|c|c|c|c|}
\hline \multirow[b]{4}{*}{ Parties } & \multirow[b]{4}{*}{ Theme } & \multicolumn{2}{|c|}{2002} & \multicolumn{2}{|c|}{2006} & \multicolumn{2}{|c|}{2010} & \multicolumn{2}{|r|}{2014} & \multicolumn{2}{|c|}{2018} & \multirow[b]{4}{*}{ Average } \\
\hline & & Time & diff. & Time & diff. & Time & diff. & Time & diff. & Time & diff. & \\
\hline & & $\%$ & Average & $\%$ & Average & $\%$ & Average & $\%$ & Average & $\%$ & Average & \\
\hline & & & $\mathrm{pp}$ & & $\mathrm{pp}$ & & $\mathrm{pp}$ & & $\mathrm{pp}$ & & $\mathrm{pp}$ & \\
\hline \multirow[t]{2}{*}{ PT } & $\begin{array}{l}\text { Social } \\
\text { welfare }\end{array}$ & 0 & -3.6 & 8.9 & 5.3 & 2 & -1.6 & 3.9 & 0.3 & 3.1 & -0.5 & 3.6 \\
\hline & Economy & 13 & 4 & 11.5 & 2.5 & 5.5 & -3.5 & 4.4 & -4.6 & 10.6 & 1.6 & 9 \\
\hline \multirow[t]{2}{*}{ PSDB } & $\begin{array}{l}\text { Social } \\
\text { welfare }\end{array}$ & 1 & -0.4 & 0.9 & -0.5 & 1.5 & 0.1 & 2.9 & 1.5 & 0.7 & -0.7 & 1.4 \\
\hline & Economy & 6 & 4.2 & 1.7 & -0.1 & 0 & -1.8 & 0 & -1.8 & 1.5 & -0.3 & 1.8 \\
\hline
\end{tabular}

Source: Elaborated by the authors, with data from the CPOP-UFPR.

Table 03 shows the percentages related to the time allocated to the two themes by party. The economy accounted for an above-average percentage for both parties in 2002 and for the PT alone in 2006 and 2018. During the transition election of the FHC government, marked by economic reforms and stability, the theme gained more space. The PT focused on the economy in 2006, during an election in which the Lula government's social welfare policies began to be reflected in the party's HGPE. The strength of the economy as a theme is related to the fact that the PT stressed that it would keep the economy growing, which was a kind of commitment to voters. This was a positive theme at the time that the PT wanted to highlight it. As is well known, economic considerations weight heavily on voter choice (CAMARGO, 1999; VAVRECK, 2009), which reinforces campaign preference for the theme. In the HGBE allocated to the PT in 2010, less time was given to either theme. As for the PSDB, social welfare only gained prominence in 2014, as the PSDB needed to commit to the welfare policies that had been implemented by successive PT governments. Interestingly, the 
economy fades from the PSDB's HGBE programming over time, while it becomes more prominent in the HGPE allocated to the PT. The economy receives a little more emphasis in 2018, at a moment when the PT needed to signal what actions it would take to improve Brazil's economic growth and distance itself from accusations that PT governments had been responsible for the economic recession affecting the country at the time.

Regarding the specific themes observed in this first part of the article, the data indicate that television advertising is still a space for the thematization of the first round of an election, however this is not its standardized function, nor is it evenly distributed over time. It is clear that themes overlap with meta-campaigning and image building for the PT in all of the elections we looked at except that of 2006. This indicates partisan difference in the use of HGPE, whether in the debate on themes in general or in the use of the themes of the economy and social welfare.

The longitudinal distribution of these two themes does not reveal an increase or a decrease for both parties but only for the PT (Graphs 03 and 04), for which thematization increases year by year, with a slight drop in 2018. Thematization of HGPE is proportionally more used by the PT than the PSDB. The PSDB makes greater use of image-building and shows more non-linear change over time. We cannot say therefore that there is a temporal tendency towards thematization in respect of both parties. This can happen, but in this case only did for the PT.

This confirms our first hypothesis (H1) that HGPE is a space for the debate of propositions despite elements of personalization and image building, which stand out in the literature on campaign modernization (MAZZOLENI, 2010), however this is a feature that diverges rather than converges by party. The PT's election advertising was consistently more thematic than the PSDB's, except in 2002. The professionalization of campaigning and political marketing has not been able to foster a pasteurization of advertising, to use the term coined by Miguel (2004), according to which that there is not much convergence between parties, which are important for defining the construction of political campaign advertising from the content point of view, even where there are many changes of scenario and candidacy. 
Graph 03. Discussion of themes of social welfare and economy by parties (\%)

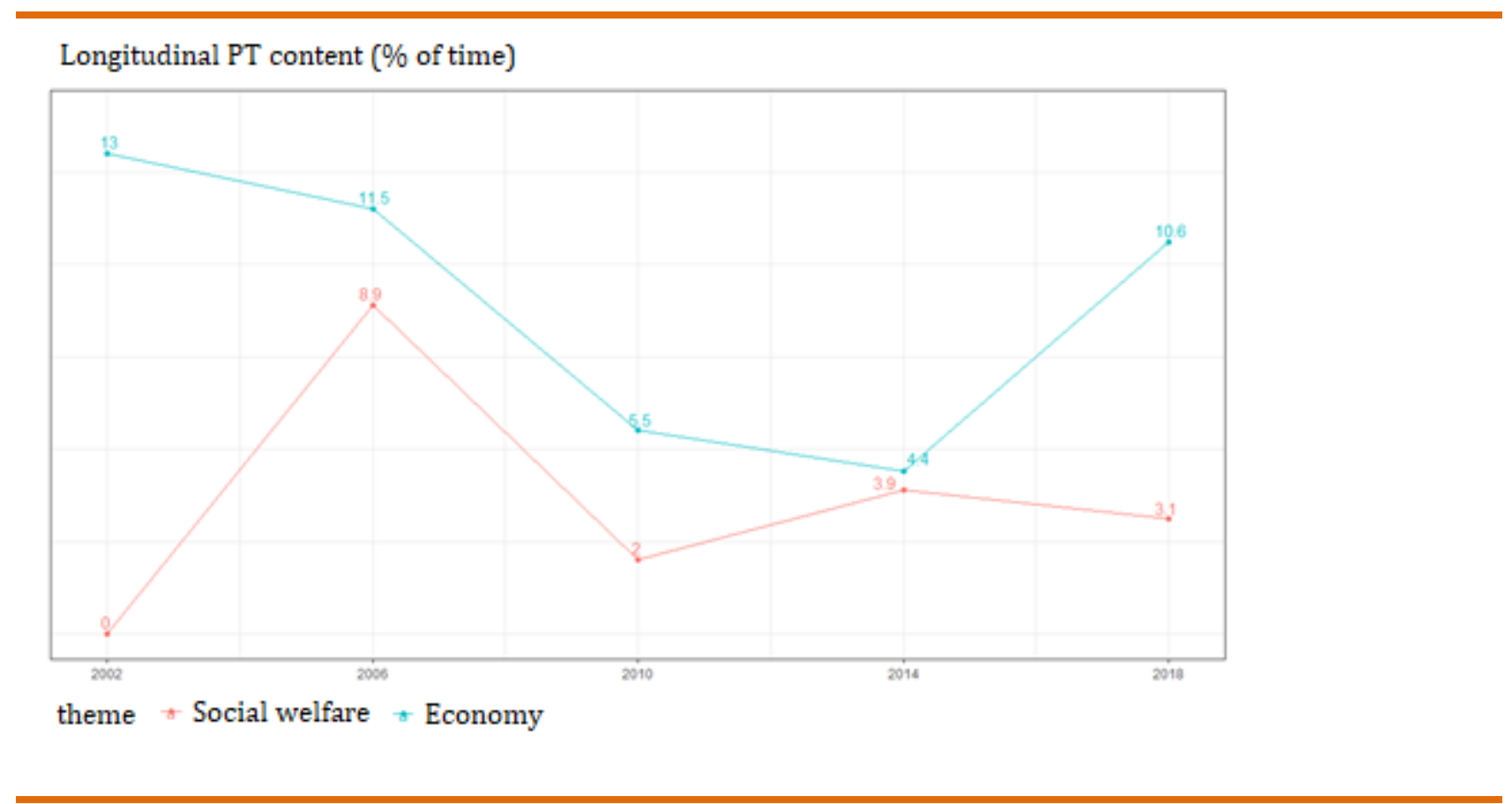

Source: Elaborated by the authors, with data from the CPOP-UFPR.

Graph 04. Discussion of themes of social welfare and economy by parties (\%)

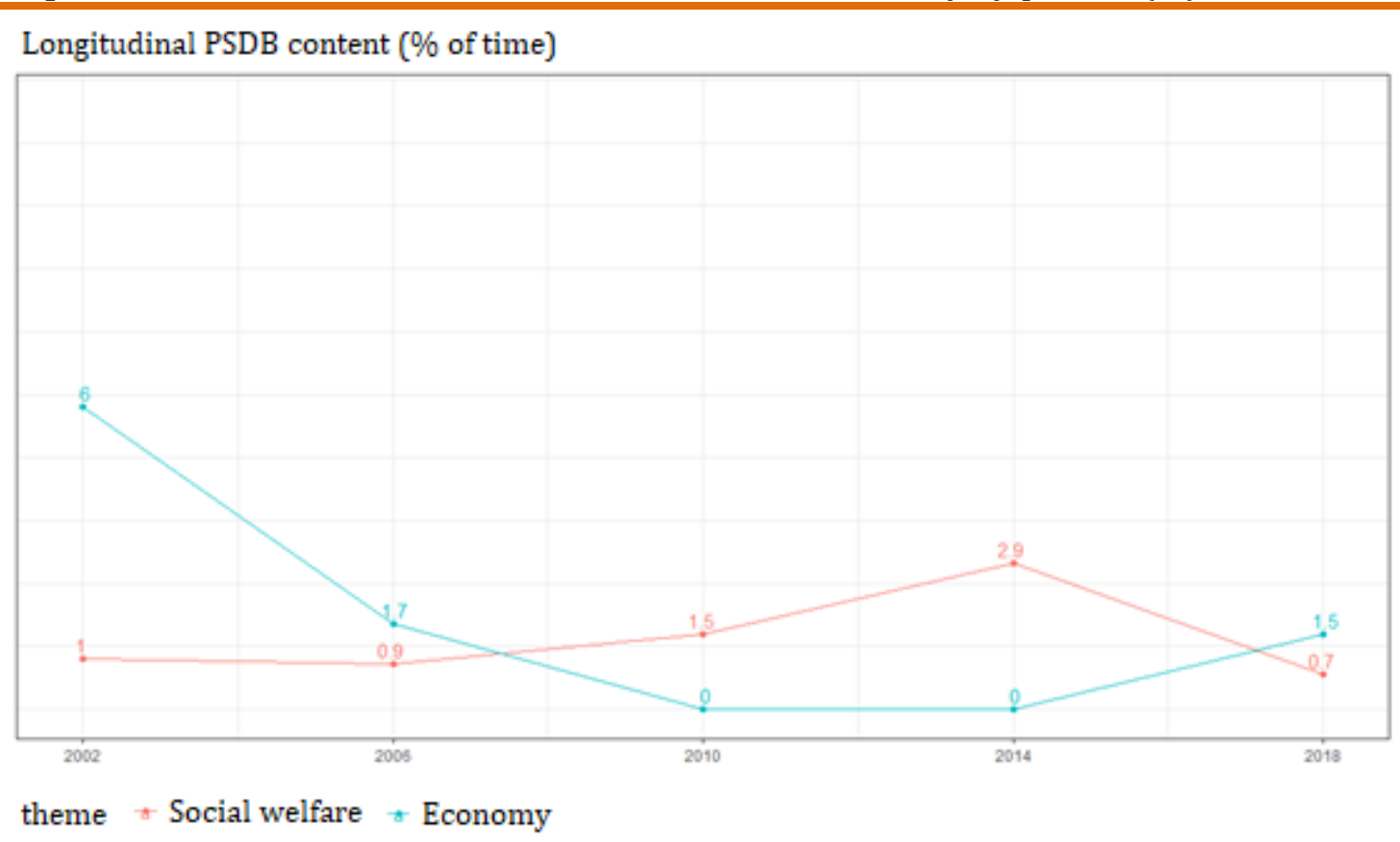

Source: Elaborated by the authors, with data from the CPOP-UFPR. 
Specifically in respect the presidential contests played out by the PT and the PSDB in the last two decades - at least as far as party centrality and coalitions are concerned - and with reference to economic and social inclusion policies, as per the literature cited above, the data showed that there was no predominance of these themes in general for either party. The economy stood out in 2002 in PT campaign advertising when Lula argued that he would guarantee the maintenance of economic stability. From then on, PT campaigns showed the results of its social development policies while in government, with less space given to the theme of the economy compared to 2002. In the case of the PSDB, the economy received even less centrality than in PT advertising. Other economic matters can arise and be debated in HGBE as a matter of course, such as employment and taxes. Few of either party's HGPE segments between 2002 to 2014 were entirely devoted to macro-economics.

\section{Discursive strategies: the importance of party positioning}

The second characteristic of the HGPE that we analyzed concerns the strategies adopted by the parties ${ }^{9}$. Table 04 indicates that the PSDB made use of more 'call for change' strategies, with 19 percentage points more than the PT, and 'attack', with 21 percentage points more. These strategies reflect the positioning of the party in the campaigns and, therefore, the results were to be expected considering that the PT was the incumbent party in every election except the 2002 one. This is related to the proposition of Figueiredo et al. (1997), on how positioning affects strategy choices. In 2018, the parties assumed different positions, with the PT opposed to the incumbent president, Michel Temer of the MDB, and the PSDB having been part of the Temer Government since 2016, following the impeachment of Dilma Rousseff. According to Figueiredo et al. (1997), these are typical characteristics of challengers and, therefore, are more typical of the PSDB in the period that the PT. By 2018, the PT was no longer in power, given the 2016 impeachment and removal from office of president Rousseff.

Although typical of one type of candidate, strategies can move between candidates. The PSDB also wished to show the competence of its candidates in previous positions and other administrative role in 35\% of its HGPE. The PT, as the incumbent

\footnotetext{
${ }^{9}$ It is noteworthy that in this case, the categories are not exclusive, and a candidate may have used more
} than one strategy during the period. 
party in three of the five elections, surpassed the PSDB in this category with $45.7 \%$ of HGPE. The PT used endorsement in $16.8 \%$ of its total HGPE, a difference of 13 percentage points in relation to the PSDB, either due to the presence of Lula endorsing Dilma Rousseff or other politicians and citizens reinforcing the campaign.

Table 04. HGPE content by party and election (2002-2018)

\begin{tabular}{lrrrrr}
\hline \multirow{2}{*}{ Variable } & \multicolumn{2}{c}{ PT } & \multicolumn{2}{c}{ PSDB } & \multicolumn{2}{c}{ Diff. Per } \\
\cline { 2 - 6 } & Time seg. & \% time & Time seg. & \% time & (PT-PSDB) \\
\hline Use of office & 18.369 & 45.7 & 14.458 & 35.1 & 11 \\
Call for change & 5.119 & 12.7 & 13.079 & 31.8 & -19 \\
Endorsement & 6.766 & 16.8 & 1.742 & 4.2 & 13 \\
Attack & 2.157 & 5.4 & 10.698 & 26 & -21 \\
\hline
\end{tabular}

Source: Elaborated by the authors, with data from the CPOP-UFPR.

From a longitudinal perspective, as shown in Table 05, it can be seen that PT built its strategies in different ways according to the election. This suggests that strategic differences are not partisan but depend on the position occupied by each party and the type of candidacy, as discussed below. In 2002, the PT employed a 'call for change' strategy, exceeding the average by more than 21 percentage points, because it was a challenger to the PSDB that had been in government for eight years. In 2006, the PT's first election as an incumbent, the party campaigned using the 'use of office' strategy 36.6 percentage points more than the average. The party had occupied the presidency for four years and was therefore able to highlight the president's experience. In 2010, it used an endorsement strategy as its presidential candidate, Dilma Rousseff, needed to be presented as a substitute for president Lula. A 'use of office' strategy was again employed in 2014, as Dilma was now the incumbent candidate. 'Attack' strategies are little used in PT campaigning, both generally and temporally, but are more common at the beginning and end of the series. A possible reason at the end is an increasing closeness to PSDB politician Aécio Neves, which called for disqualification of opponents as a form of defense. Nonetheless, the PT's use of attack strategies still accounts for a far smaller percentage than that employed by the PSDB. 
In the case of the PSDB, an 'endorsement' strategy is employed in 2002, when then candidate José Serra is presented as a replacement of FHC. 2014 and 2018 are characterized by their use of an 'attack' strategy, with high growth compared to the period as a whole. In the 2010 election, 'use of post' is employed to promote Serra for a second time, this time to highlight his experience in public administration. In 2014, with Aécio Neves as candidate, the 'attack' and 'call for change' strategies predominate. In 2006 the PSDB made little use 'call for change' strategy (less than in 2002, when it was the incumbent). Use of this strategy grew in 2010 and 2014. There are few examples of 'attack' in 2002, when PSDB was the incumbent, but these grew in later years when the party was the challenger candidate.

Table 05. HGPE strategies by party and election

\begin{tabular}{|c|c|c|c|c|c|c|c|c|c|c|c|c|}
\hline & & \multicolumn{2}{|c|}{2002} & \multicolumn{2}{|c|}{2006} & \multicolumn{2}{|c|}{2010} & \multicolumn{2}{|c|}{2014} & \multicolumn{2}{|c|}{2018} & \multirow[b]{2}{*}{ Average } \\
\hline & & $\begin{array}{l}\text { Time } \\
\text { seg. }\end{array}$ & $\begin{array}{c}\text { diff. } \\
\text { Average } \\
\text { pp }\end{array}$ & $\begin{array}{l}\text { Time } \\
\text { seg. }\end{array}$ & $\begin{array}{c}\text { diff. } \\
\text { Average } \\
\text { pp }\end{array}$ & $\begin{array}{l}\text { Time } \\
\text { seg. }\end{array}$ & $\begin{array}{c}\text { diff. } \\
\text { Average } \\
\text { pp }\end{array}$ & $\begin{array}{l}\text { Time } \\
\text { seg. }\end{array}$ & $\begin{array}{c}\text { diff. } \\
\text { Average } \\
\text { pp }\end{array}$ & $\begin{array}{l}\text { Time } \\
\text { seg. }\end{array}$ & $\begin{array}{c}\text { diff. } \\
\text { Average } \\
\text { pp }\end{array}$ & \\
\hline \multirow[t]{4}{*}{ PT } & Use of office & 7.1 & -36 & 79.7 & 36.6 & 30.4 & -12.7 & 59.2 & 16.1 & 39.2 & -3.9 & 43.1 \\
\hline & $\begin{array}{l}\text { Call for } \\
\text { change }\end{array}$ & 35.5 & 21.2 & 0 & -14.3 & 12.1 & -2.2 & 10.7 & -3.6 & 13.1 & -1.2 & 14.3 \\
\hline & Endorsement & 4.9 & -11.8 & 0.7 & -16 & 32.9 & 16.2 & 11.2 & -5.5 & 34 & 17.3 & 16.7 \\
\hline & Attack & 10.4 & 4 & 2.9 & -3.5 & 0.3 & -6.1 & 7.7 & 1.3 & 10.6 & 4.2 & 6.4 \\
\hline \multirow[t]{4}{*}{ PSDB } & Use of office & 32.2 & -2.4 & 43.9 & 9.3 & 55.2 & 20.6 & 27 & -7.6 & 14.8 & -19.8 & 34.6 \\
\hline & $\begin{array}{l}\text { Call for } \\
\text { change }\end{array}$ & 36.2 & 0 & 14.3 & -21.8 & 42.8 & 6.7 & 63.8 & 27.7 & 23.6 & -12.5 & 36.1 \\
\hline & Endorsement & 8.1 & 3.9 & 4.3 & 0 & 2.5 & -1.8 & 5.9 & 1.6 & 0.3 & -4 & 4.3 \\
\hline & Attack & 7.5 & -19.7 & 25.5 & -1.7 & 21 & -6.2 & 38.5 & 11.3 & 43.7 & 16.5 & 27.2 \\
\hline
\end{tabular}

Source: Elaborated by the authors, with data from the CPOP-UFPR.

As Graphs 05 and 06 show, the two parties' strategies differ. This is because, unlike format or themes, strategy in an electoral contest is more related to the position and posture of the parties and candidates in each election than to any strategic tendency that may have gained prominence over time due to the modernization of political communication (MAZZOLENI, 2010). Even 'attack', which Borba (2015) shows to have grown compared to other strategies, stands out only when the need for its use is perceived from the context of the candidates and their position. Longitudinal growth can be seen by observing the PSDB and its significant use of 'attack' and 'call for change' strategies in every election. However, the same cannot be said of the PT, in which the most significant attack data only appear when the party is the challenger (i.e. in 2002 and 2018). We cannot therefore say that use of this feature has gained more visibility over time. 


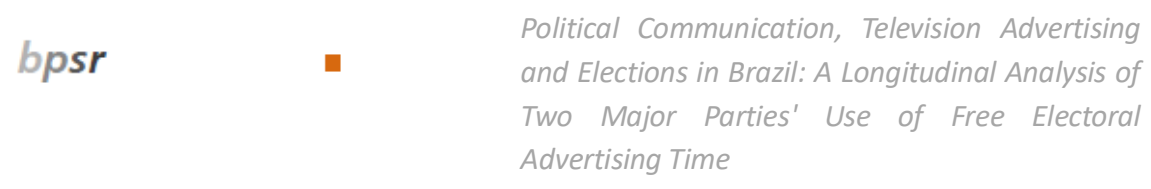

Strategies vary between parties and over time without an apparent pattern. This is explained by the position of each party (incumbent or challenger) and the context of the election, since the longitudinal graphs indicate many changes. The scenario of the elections in each year and the relative positions of the candidates (challengers or representatives) can help us understand significant differences in use of HGPE rather than partisan or temporal considerations. Figueiredo et al. (1997) have already demonstrated that the use of HGPE by candidates depends on their position in the election. This is clear from the analysis of the five elections we looked at and the variations that occur in each one. Thus, as can be seen from our results, the PT stood out for its distinctively high employment of the 'use of office' strategy due to its being the incumbent party in the majority of the elections. The fall in the use of this strategy in 2018 reflects that PT's position of challenger in that election. The PSDB, as the challenger in four of the five elections, most often had recourse to a 'call for change' strategy. The strategy of 'endorsement' was favored by the PT campaign in 2010, with Lula presenting Dilma to the electorate (TAVARES, 2013), but was not called on in 2014 , when it is no longer needed.

Graph 05. The PT and the PSDB's HGPE strategies - longitudinal (2002-2018)

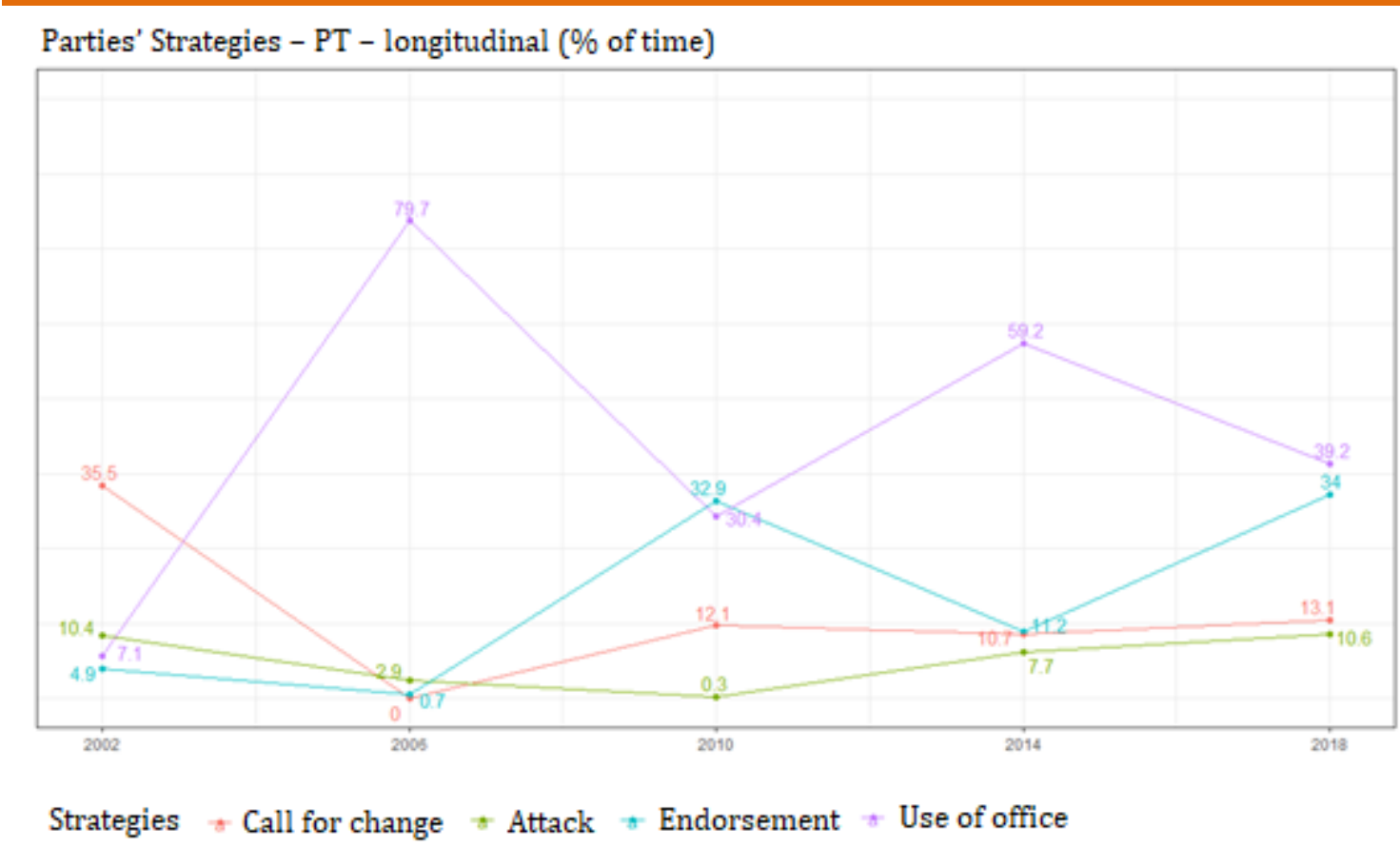

Source: Elaborated by the authors, with data from the CPOP-UFPR. 
Year-on-year variation can be seen longitudinally according to the position of each party and the characteristics of the candidates themselves. This does not indicate that one strategy has become more favored or that HGPE content production has changed over time. Context, candidate type and candidate's relative position are the variables that explain the differences that appear over time, and there are no linear changes between candidates or shared by them as they occupied distinct positions. Our second hypothesis (H2), that strategies vary according to a given candidate's position in an election (incumbent or challenger), is therefore confirmed. In addition, non-linear variation occurs for all strategies and not just for 'attack' and use of political support.

Graph 06. The PT and the PSDB's HGPE strategies - longitudinal (2002-2018)

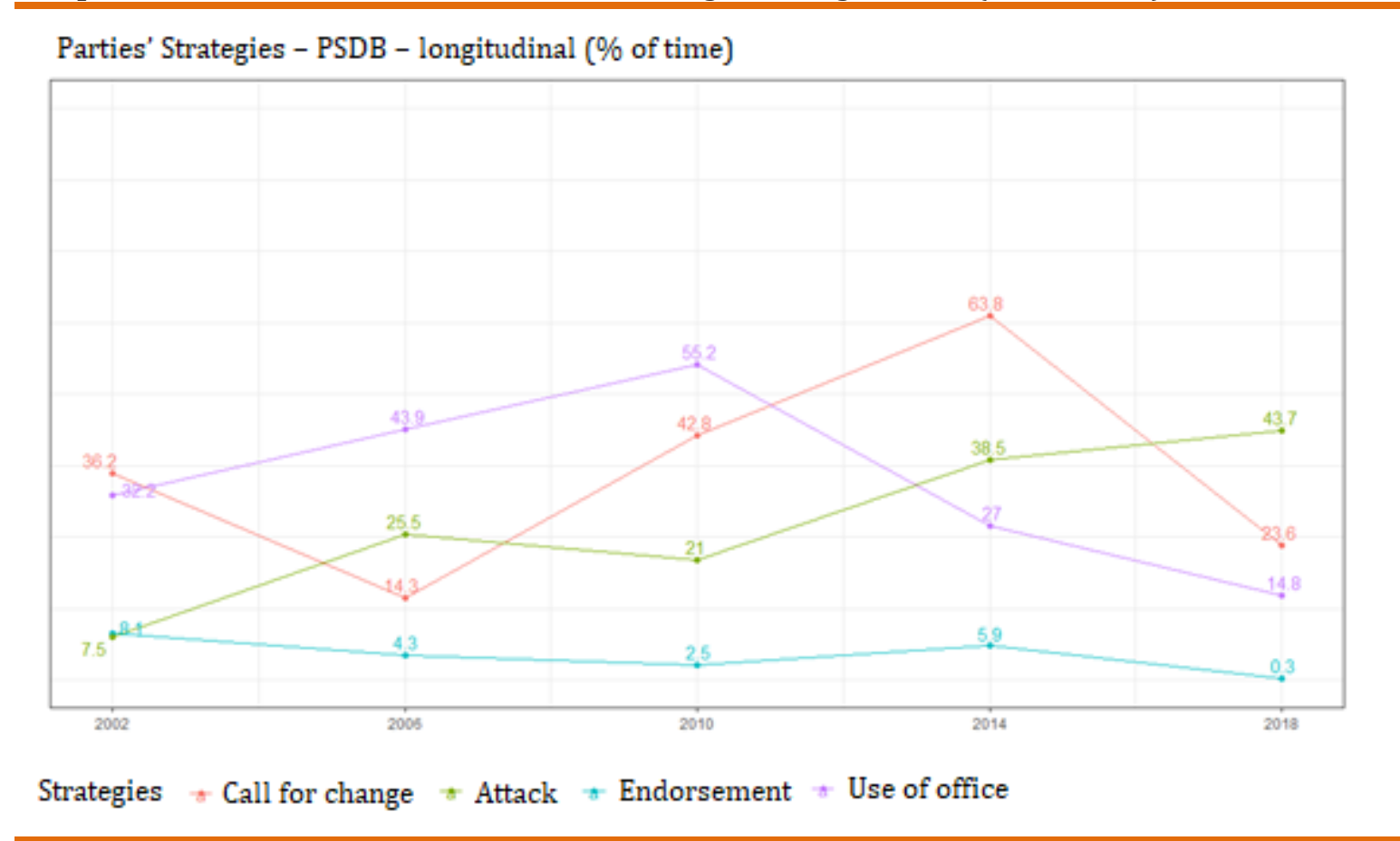

Source: Elaborated by the authors, with data from the CPOP-UFPR.

Despite the importance of each party's context and relative position, one item demonstrates some stability among electoral advertising strategies employed by both parties: 'use of office'. Although more favored by the PT, 'use of office' was also central to PSDB strategy, even though it is typically used by incumbents (Figueiredo et al., 1999) and the PSDB was the challenger in three of the five elections. This is because the presidential candidate normally has a political career to demonstrate experience and credibility in administration. 


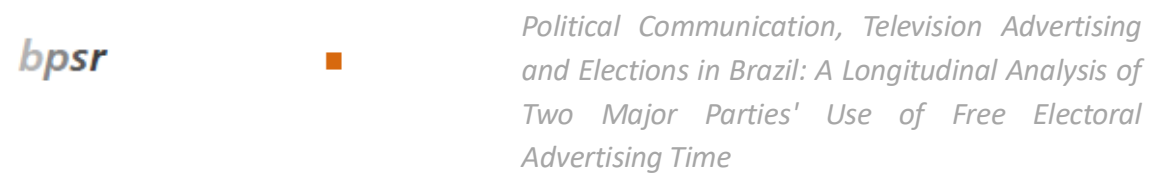

The 'use of office' strategy was widely employed by both parties to highlight their candidate's experience, regardless of his or her relative position in the election. In the case of the PSDB, this is explained by its frequent change of candidate and the fact that its candidates had acted in other roles. This can be understood as a complement to the image building so prevalent in the PSDB's use of HGPE. 'Use of office' was the strategy most used by PSDB and PT in three elections (2006, 2014 and 2018 for the PT and 2006 and 2010 for the PSDB). In other elections the PT favored 'call for change' in 2002 and 'endorsement' in 2010, with 'use of office' coming in second in each case. The PSDB favored 'call for change' over 'use of office' in 2002 and 2014 and 'attack' over 'use of office' in 2018.

It is also important to note that although the literature (BORBA, 2015) shows gradually increased use of negative campaigning, especially in Brazil, block HGPE election advertising by the PSDB and the PT shows no evidence of generalized growth of 'attack' strategies. 'Attack' is typical of challengers and growth in the use of this tactic is found in the PSDB's use of HGPE only. We remind readers that this study only considers the first rounds of the elections in question, where multiple candidates are in dispute and we expect more debate and less confrontation than in the second round, when the election gets tough.

\section{Final considerations}

The purpose of this article is to investigate how the PSDB and the PT used their the HGPE in the five elections held between 2002 and 2018. It presents a comparison between the parties regarding the use of two characteristics - content and strategy and how time influenced the way these elements were used. Its main purpose was to identify similarities and differences between the parties, as well as to verify whether over time some characteristics became more or less absent from advertising, regardless of each party's choices, and to identify changes in the dynamics of HGPE use over time, as it has been an important element of political campaigning since at least 1989. The 1994 and 1998 elections were not considered for methodological reasons, since the database we analyzed only contains electoral advertising from 2002 onwards. Of the five elections we looked at, the only once where the PT and the PSDB were not the main contenders was that of 2018.

(2021) 15 (3) - e0003-26/33


The choices we made to create our research dataset did not allow us to address HGPE use in its entirety. The elections we looked at were first-past-the-post contests featuring large, professionalized parties, with substantial resources and ample HGPE time. Their shared characteristics could bring the PT and the PSDB closer to one another. Limited HGPE time also imposes different uses. Other analyses could certainly be made of other contexts not considered in the scope of this article.

Regarding both party and temporal differences, it is important to emphasize that we analyzed two characteristics only; i.e. we did not analyze format, appeal or language, all of which may also reveal divergences and developments in their use of advertising. Our objective was to focus on content. We limited our study to the first rounds of the elections we analyzed. This was necessary for our comparison since in the second round, when the parties have longer and equal HGPE, they can adopt strategies, formats and content that differ from those used in the first round.

Despite the necessarily limited scope of our research, our results provide important elements for the understanding of HGPE as a campaign tool. The extent to which HGPE is thematized depends on the relative position of the parties, as per our first hypothesis hypothesis (H1). Temporal change that might have transformed 'different' into 'equal' does not seem as relevant as party distinctions that are maintained over time. By contrast, the longitudinal distribution of themes does not indicate an increase or decrease for both parties, but only for the PT. Therefore, the PT, in addition to being more thematic than the PSDB in each election, with the exception of 2002, shows significant growth in thematic HGPE. The PSDB oscillates between a focus on image and one on themes. Therefore, themes are a stronger campaign feature for the PT, one which proportionally gains more space year by year. In this sense, the differences between the parties are more explanatory than the temporal aspect for understanding the thematization of election campaigns. This is a finding that highlights the relevance of parties in Brazilian electoral contests. From 2002 to 2016, the PT made considerable investments in public policies to reduce social inequality. This was a topic that did not gain prominence in PSDB campaigns in the FHC era, but which has become central to campaigning since then. The economy tends to be highlighted in election campaigns that take place during recessions, with the two 


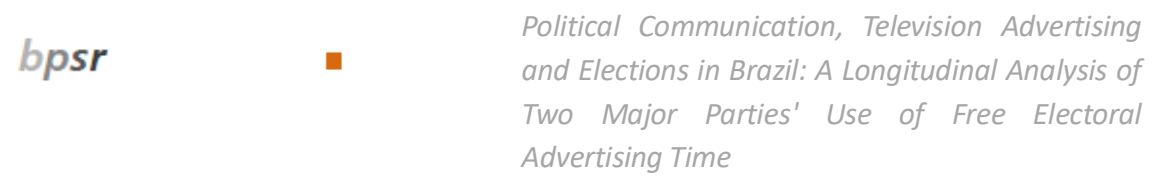

parties distinguishing themselves from each other via HGPE, especially in the case of the more neoliberal PSDB.

Our second hypothesis (H2) that strategies vary according to a given candidate's position in an election, with no significant temporal or partisan influence, was also vindicated by our findings, which showed that regardless of party and time between disputes, some strategies were repeated according to the positioning of the candidate. Thus, the variation of discursive strategy is seen election by election and occurs according to the party's relative position and the characteristics of the candidates themselves. This suggests that strategies do not 'grow' longitudinally - over time - and do not reflect change due to party matters.

Changes in discourse, it seems, occur over time and have no apparent direction or linearity. Therefore, they are not cyclical, as per Stimson's proposal (1976). Context, candidate type and candidate's relative position are the variables that explain the differences that appear over time, and there are no linear changes between candidates or shared by them as they occupied distinct positions. Disorderly variation within parties and over time occurs for all strategies and not only for some of them. We can therefore say that the proposal of Figueiredo et al. (1997) remains relevant, at least for understanding and explaining the use of HGPE in national elections.

Thus, despite its limitations, we believe that this work makes two central contributions to the field. The first of these is a comparative contribution that explores the use made of HGPE by the PSDB and the PT. This is in line with other studies that seek to perceive party differences (CERVI, 2016; D'ARAUJO, 2011); here the focus has been on how they express themselves in election campaigns using HGPE. We also sought to make observations that went beyond just one election and allowed us to look empirically at the broader campaign-building process between the two parties over five elections. This longitudinal study constitutes research on political advertising and HGPE, which remains rarely mentioned in the literature.

Translated by Eoin Portela Submitted on October 14, 2019 Accepted on August 18, 2020 


\section{References}

ALBUQUERQUE, Afonso de (2009), Notas para uma agenda da pesquisa sobre a propaganda política na televisão no Brasil. ECO-PÓS. Vol. 12, № 03, pp. 04-10.

ALBUQUERQUE, Afonso de (1999), Aqui você vê a verdade na tevê: a propaganda política na televisão. Niterói: UFF. 204 pp..

ALBUQUERQUE, Afonso de; STEIBEL, Fabro Boaz, and CARNEIRO, Carolina Maria Zoccoli (2008), A outra face do horário gratuito: Partidos políticos e eleições proporcionais na televisão. DADOS. Vol. 02, № 51, pp. 459-487.

ALBUQUERQUE, Afonso de and TAVARES, Camilla (2019), Horário gratuito de propaganda eleitoral: estilo, estratégias, alcance e os desafios para o futuro. In: 25 anos de eleições presidenciais no Brasil. Edited by FIGUEIREDO, Argelina Cheibub and BORBA, Felipe. Curitiba: Appris. pp. 147-169.

BAUER, Martin W. and GASKELL, Georgs (2012), Pesquisa qualitativa com texto, imagem e som: um manual prático. Petrópolis: Ed. Vozes. 520 pp..

BORBA, Felipe (2015), Propaganda negativa nas eleições presidenciais brasileiras. Opinião Pública. Vol. 21, № 02, pp. 268-295.

BORBA, Felipe and MEDEIROS, Luiza da Silva (2019), . O HGPE e a democracia brasileira: as eleições de 2014 e 2018 em perspectiva comparada. Paper. Anais do Congresso da Compolítica. Brasília.

BORGES, André and VIDIGAL, Robert Lee (2018), Do lulismo ao antipetismo? Polarização, partidarismo e voto nas eleições presidenciais brasileiras. Opinião Pública. Vol. 24, № 01, pp. 53-89.

BRASIL (2016), Presidência da República. Pesquisa brasileira de mídia 2016: hábitos de consumo de mídia pela população brasileira. Brasília: Secom. Available at $<$ <ttp://www.secom.gov.br/atuacao/pesquisa/lista-de-pesquisas-quantitativas-equalitativas-de-contratos-atuais/pesquisa-brasileira-de-midia-pbm2016.pdf/view>. Accessed on January, 30, 2020.

BRASIL (1997), Lei 9.504 de 30 de setembro de 1997. Available at $<$ http://www.planalto.gov.br/cciviL_03/leis/L9504.htm>. Accessed on January, 30, 2020.

CAMARGO, Malco B. (1999), Do bolso para as urnas: a influência de economia na escolha entre Fernando Henrique e Lula nas eleições de 1998. Master's dissertation. Programa de Pós-Graduação em Ciência Política. Instituto Universitário de Pesquisas do Rio de Janeiro.

CARNEIRO, Leandro Piquet and SCHMITT, Rogério Augusto (1995), Eleições casadas, resultados nem sempre solteiros: campanhas proporcionais e imagem partidária no horário gratuito de propaganda eleitoral. Opinião Pública. Vol. 03, № 01, pp. 6487. 


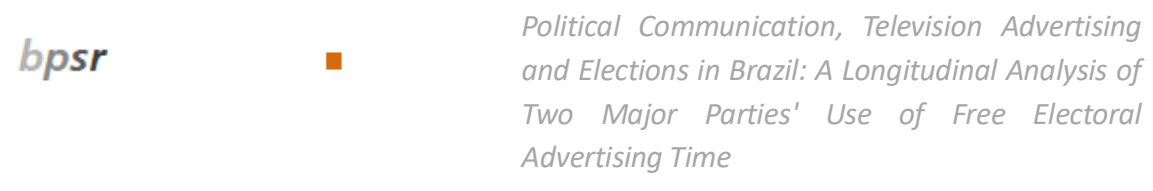

CARREIRÃO, Yan de Souza (2006), Ideologia e partidos políticos: um estudo sobre coligações em Santa Catarina. Opinião Pública. Vol. 12, № 01, pp. 136-163.

CERVI, Emerson Urizzi (2016), PSDB e PT em eleições nacionais: fatores geográficos, políticos e socioeconômicos na polarização partidária no Brasil (1994 e 2014). Salamanca: Flacso-es/Curitiba: CPOP. 343 pp..

CERVI, Emerson Urizzi (2011), 0 uso do HGPE como recurso partidário em eleições proporcionais no Brasil. Opinião Pública. Vol. 17, № 01, pp. 106-136.

DATAFOLHA (2002), FHC encerra mandato com reprovação maior do que aprovação. Relatório de Opinião Pública. 15 de dezembro de 2002. Available at $<$ http://datafolha.folha.uol.com.br/opiniaopublica/2002/12/1222326-fhc-encerramandato-com-reprovacao-maior-do-que-aprovacao.shtml>. Accessed on July, 12, 2020.

D'ARAUJO, Maria Celina (2011), PSDB e PT e o Poder Executivo. Desigualdade \& Diversidade. Dossiê especial. S/N, pp. 65-100.

DIAS, Marcia Ribeiro (2013), Nas brumas do HGPE: a imagem partidária nas campanhas presidenciais brasileiras (1989 a 2010). Opinião Pública. Vol. 19, № 01, pp. 198-219.

DIAS, Marcia Ribero (2012), Republicanismo adjetivado: as dimensões aristocrática e democrática nos discursos da campanha presidencial brasileira de 2006. Revista Compolítica. Vol. 02, № 01, pp. 29-60.

DIAS, Lucia Moreira and FERNANDES, Carla Montuori (2020), Campanha de Jair Bolsonaro para presidência em 2018: a construção do Mito Político. ECCOM. Vol. 11, № 22, pp. 477-488.

FIGUEIREDO, Argelina Cheibub; LIMONGI, Fernando, and VALENTE, Ana Luzia (1999), Governabilidade e concentração de poder institucional: o governo FHC. Tempo Social. Vol. 11, № 02, pp. 49-62.

FIGUEIREDO, Marcus; ALDÉ, Alessandra; DIAS, Heloísa, and JORGE, Vladimyr L. (1997) Estratégias de persuasão eleitoral: uma proposta metodológica para o estudo da propaganda eleitoral. Opinião Pública. Vol. IV, № 03, pp. 182-203.

FREITAS, Felipe Corral de (2018), 0 primeiro grande antagonismo entre PSDB e PT. Opinião Pública. Vol. 24, № 03, pp. 547-595.

HOLTZ-BACHA, Christina and KAID, Linda Lee (2006), The sage Handbook of Political advertising. Londres: Sage Publication. 504 pp.. 
IBGE (2017), Pesquisa nacional por amostra de domicílios contínua. Site. Available at <https://www.ibge.gov.br/estatisticas/sociais/populacao/17270-pnadcontinua.html>. Accessed on January, 27, 2020.

KRIPPENDORFF, Klaus (1990), Metodologia de análisis de contenido: teoría y práctica. Barcelona: Paidós. 280 pp..

LAU, Richard R.; SIGELMAN, Lee; HELDMAN, Caroline, and BABBITT, Paul (1999), The effects of negative political advertisements: a meta-analytic assessment. American Political Science Review. Vol. 93, № 04, pp. 851-875.

LIMONGI, Fernando and GUARNIERI, Fernando (2014), A base e os partidos: as eleições presidenciais no Brasil pós-redemocratização. Novos Estudos. № 99, pp. 05-24.

LOURENÇO, Luís Claudio (2009), Propaganda negativa: ataques versus votos nas eleições presidenciais de 2002. Opinião Pública. Vol. 15, № 01, pp. 133-158.

MACHADO, Mônica (2009), A retórica da reeleição: mapeando os discursos dos programas eleitorais (HGPE) em 1998 e 2006. Opinião Pública. Vol. 15, № 01, pp. 159-189.

MADEIRA, Rafael M.; VIEIRA, Soraia M., and TAROUCO, Gabriela (2017), Agendas, preferências, competição: PT e PSDB em disputas presidenciais. Caderno CRH. Vol. 30, № 80, pp. 257-273.

MANCINI, Paolo and SWANSON, David L. (1996), Politics, media and modern democracy: an international study of innovations in electoral campaigning and their consequences. Westport: Praeger. 300 pp..

MARQUES, Francisco Paulo Jamil and CARNEIRO, Aline Mendonça Conde (2018), Corações, mentes e estratégias: a relação entre "marqueteiros" e políticos durante as eleições de 2012 em Fortaleza. Revista de Sociologia e Política. Vol. 26, № 65, pp. 105-131.

MASSUCHIN, Michele Goulart; TAVARES, Camilla Quesada; CARVALHO, Fernanda Cavassana, and LIMA, Regiane Soares (2016), A construção da campanha eleitoral majoritária no HGPE: uma análise comparada das estratégias usadas pelos presidenciáveis de 2014. Política \& Sociedade. Vol. 15, № 32, pp. 171-203.

MAZZOLENI, Gianpietro (2010), La comunicación política. Madrid: Alianza Editorial. 344 pp..

MIGUEL, Luis Felipe (2009), Apelos discursivos em campanhas proporcionais na televisão. Política \& Sociedade. Vol. 16, № 09, pp. 151-175.

MIGUEL, Luis Felipe (2004), Discursos cruzados: telenoticiários, HPEG e a construção da agenda eleitoral. Sociologias. № 11, pp. 238-258. 


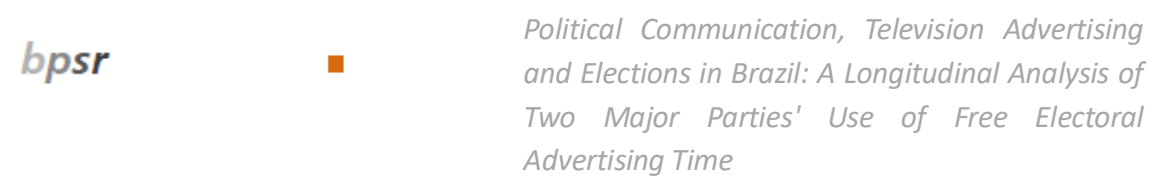

OLIVEIRA, Luiz Ademir and MARTINS, Thamiris Franco (2013), As estratégias retóricas utilizadas por Dilma e Serra no primeiro turno do HGPE de 2010. Revista Científica da Faminas. Vol. 09, № 03, pp. 93-114.

PANKE, Luciana and CERVI, Emerson (2011), Análise da comunicação eleitoral: uma proposta metodológica para os estudos do HGPE. Contemporânea. Vol. 09, № 03, pp. 390-404.

PENDIUK, Fabio (2013), Cenários e campanhas: imagens de Curitiba e Porto Alegre nas propagandas eleitorais de 2004 e 2008. Doctoral thesis. Programa de PósGraduação em Sociologia. Departamento de Ciências Sociais. Universidade Federal do Paraná.

PORTO, Mauro Pereira and GUAZINA, Liziane Soares (1999), A política na TV: o horário eleitoral da eleição presidencial de 1994. Contracampo. Vol. 03, pp. 05-33.

REIS, Fábio Wanderley (2014), Eleição de 2014: 'País dividido' e questão social. Em Debate. № 06, pp. 08-16.

SCHMITT, Rogério Augusto; CARNEIRO, Leandro Piquet and KUSCHNIR, Karina (1999), Estratégias de campanha no horário gratuito de propaganda eleitoral em eleições proporcionais. Dados. Vol. 42, № 02, s/p.

SILVA, Adriano da Nobrega (2012), A associação de questões aos partidos políticos e as eleições presidenciais no Brasil. E-Legis. № 09, pp. 52-64.

SOUZA, Nelson Rosário de; CERVI, Emerson Urizzi, and SANTOS, Sandra Avi dos (2009), Mídia e eleições em Curitiba: estratégias discursivas do PT e do PSDB em 2004 e 2008. Paper. Anais do 33ํㅡㄹ Encontro Anual da Anpocs. Caxambu.

STIMSON, James A. (1976), Public support for American presidents: a cyclical model. Public Opinion Quarterly. Vol. 40, № 01, pp. 01-21.

STRÖMBÄCK, Jesper (2008), Political marketing and professionalized campaigning. Journal of Political Marketing. Vol. 06, № 02-03, pp. 49-67.

TAVARES, Camilla Quesada (2013), 'Para Presidente, vote na gente': as personalidades presentes nos programas do PT e PSDB veiculados no horário eleitoral de 2002, 2006 e 2010. Master's dissertation. Programa de Pós-Graduação em Ciências Sociais Aplicada. Universidade Estadual de Ponta Grossa.

TELLES, Helcimara de Souza and MUNDIM, Pedro Santos (2015), Comportamento eleitoral e comunicação política. In: Voto e estratégias de comunicação política na América Latina. Edited by TELLES, Helcimara de Souza and LAVAREDA, Antonio. Curitiba: Appris. pp. 15-39. 
TRIBUNAL SUPERIOR ELEITORAL (2020), Repositório de dados eleitorais. Available at <https://www.tse.jus.br/eleições/estatisticas/repositorio-de-dados-eleitorais-1>. Accessed on November, 15, 2020.

VEIGA, Luciana Fernandes (2017), Em busca das razões para o voto: o uso que o eleitor faz do horário eleitoral. In: Eleições, opinião pública e comunicação política no Brasil contemporâneo. Edited by BORBA, Felipe and ALDÉ, Alessandra. Rio de Janeiro: Eduerj. pp. 185-210.

VAVRECK, Lynn (2009), The message matters: the economy and presidencial campaigns. Princeton: Princeton University Press. 232 pp.. 